\title{
SOBRE O ENSINO PRIMÁRIO PÚBLICO
}

\section{Apresentação}

Trata-se aqui de trazer à tona excertos da obra de Sílvio Romero [1851-1914], Ensaios de Sociologia e Litteratura. Rio de Janeiro: H. Garnier, Livreiro-Editor, 1901, em particular do tópico IV - Notas sobre o ensino público, p. 125-216, escrito em 1890, conforme datação ao final, à p. 216. O autor em apreço é sergipano de nascimento, foi crítico literário, poeta, filósofo, professor e político. É ilustrativo o referido tópico, seja quanto ao período que antecede a emergência dos grupos escolares - desde primeiramente em São Paulo, efetivados a partir de 1894 -, seja quanto à discussão sobre os rumos que o ensino primário, a seu ver, deveria tomar sob a responsabilidade da União.

A título de esclarecimento, o referido tópico $I V$ inclui em seu interior seis subtítulos assim numerados: I - O ensino e a União; II - Liberdade de ensino em geral. Obrigatoriedade do primário; III - Espírito do ensino, principalmente primário e secundário; IV - O ensino e o caráter nacional. Competência do Estado; V - Ainda a ação do Estado. Exames; VI Organização do ensino secundário. O Ginásio Nacional.

O excerto reproduzido a seguir espelha o item $I-O$ ensino e a União, p. 127-133. O seu teor compõe-se de análise e posições sobre o papel da União em relação aos níveis primário, secundário e superior. Suas posições são relativamente presentes quanto ao papel que o ensino primário deveria ter na configuração do caráter nacional. Em termos de contextualização, a República brasileira acabara de nascer, o analfabetismo andava na casa dos $85 \%$, a escola primária manifestava-se precariamente, o federalismo e o republicanismo triunfaram eivados de positivismo, evolucionismo e cientificismo, além da política pautar-se sob a tutela do coronelismo e do clientelismo. Nesse sentido, os tempos políticos eram de descentralização, e de responsabilização estadual em torno da escola primária pública.

José Carlos Souza Araujo 


\title{
IV - NOTAS SOBRE O ENSINO PÚBLICO
}

\author{
I - O ensino e a União
}

"O que pretendemos escrever sobre o ensino público entre nós vai ser mui diverso de tudo quanto n'este paiz tem sido publicado n'esta matéria nos derradeiros vinte annos.

E vai ser differente, não porque o julguemos melhor; pois que não somos tão insensatos, como a muitos agradaria acreditar; e sim porque, em vez de um tecido de citações, como é de moda em taes assumptos, preferiremos dar apenas a nossa opinião particular, oriunda da pratica do magistério, sem a mais leve preoccupação, o mais das vezes, do que se pratica lá fora. Nossa leitura pedagógica não é, infelizmente, muito vasta e, por isso, se nos antolha mais acertado dizer o que temos visto e examinado por nossos próprios olhos do que cercarmo-nos agora de livros e caminhar nos hombros dos outros. De pedagogices livrescas já andamos de sobra gafos, e o ensino n'esta terra começou a desandar justamente, exactamente depois que entramos a encher a bocca de palavrões sonoros e farfalhantes, como recentes processos, modernas orientações, intuições realistas, instrucção integral... et le reste! Um tal ou qual conhecimento da índole do povo, que resuminos ter, por havel-o estudado sob formas varias, quer parecer-nos, ás vezes, que nos habilita a dizer alguma cousa que não é de todo para desprezar.

E, pois, vamos ao assumpto e sem mais preâmbulos.

A questão do ensino publico entre nós só terá um sentido racional, quando for presa á questão geral de nossa organisação política e ainda mais ás nossas condições sociaes, e for um desdobramento normal de nossas aptidões ethnicas e históricas. Fóra d'esse plano tudo quanto se disser será, talvez muito bonito no papel, mas sem o mínimo valor no terreno maninho da applicação e da pratica.

Temos nós aqui o ensino primário, o secundário, o superior e o normal mais ou menos organisados. Mas quaes são os agentes, os factores d'esses vários ramos da instrucção?

A União, os Estados, as municipalidades, as associações, os indivíduos; é a resposta, por assim dizer theorica, que não esclarece a realidade positiva dos factos. É assim que o ensino primário escapa de todo á influencia da União, o normal completamente lhe sahiu das mãos, e o secundário e superior lhe vão fugindo, e, até certo ponto, com razão.

Será isto acertado sob todos os pontos de vista?

Bem sabemos que é hoje uma opinião repetida e rebutalhada em todos os sentidos e conveniência de retirar do Estado um certo numero de funcções deixal-as á sociedade, que fará da se. Credos políticos e philosophicoss de cores diversas, separados em questões múltiplas e variadissimas, estão, entretanto, de accordo neste ponto. Mas n'uma Republica federativa, onde á União cabe a funcção suprema de manter a cohesão nacional, será de bom aviso tirar-lhe toda e qualquer ingerência no ensino publico?

A fiscalisação dos governichos dos Estados, com sua politiquice ossificada, com suas preoccupações motinas de cambalaxos de campario, será a mais conveniente sob todos os 
aspectos e em toda a linha? Eis a questão, a que vamos responder, não consultando os tratados dos estrangeiros; mas abrindo o livro de nossa experiência individual.

Do ensino primário e normal não se cogita na Constituição da República. Alli só se fala no ensino secundário e superior. Quanto a estes a União reservou-se, mas não privativamente, o direito de provel-os nos Estados e no Districto Federal (Art. 35, $\S \S 3^{\circ}$. e $4^{\circ}$ ). Terá sido bem inspirado o legislador constituinte? Duvidemos. A questão do ensino é uma das que devem ser retocadas no texto constitucional, mas para conferir á União a direcção do ensino superior, do normal e todo o secundário, senão para the entregar pura $\mathrm{e}$ completamente o ensino primário. Raciocinemos.

O ensino superior é, por sua complexidade, por suas tendências especialistas, nas sociedades modernas a preparação technica para certas e determinas funcções e carreiras. Pressuppõe um largo desenvolvimento da cultura geral, uma vida social adiantada, onde singulares necessidades apparecem e procuram naturalmente sua própria realisação. N'esses centros progressivos, onde a expansão intellectual é uma resultante da própria existência do aggregado político e nacional, o ensino superior surge espontaneamente, inilludivelmente, como uma funcção da sociedade mesma e os governos podem perfeitamente abrir mão de sua direcção sem prejuízos e sem abalos. A instrucção superior é, póde-se dizer, um luxo, que cabe relativamente a poucos.

Não é tudo: é um ensino que, versando sobre os mais árduos pontos doutrinários, involve necessariamente a vexata questio da religião e da philosophia de cada um, terreno em que o Estado não tem que pôr o pé sob pena de disparatar. Em taes condições, nem mesmo á União caberia ter na Capital Federal escolas superiores que fossem modelos para servirem, si et in quantum, de paradigmas para se moldarem por ellas as creações congêneres da iniciativa particular e social deixando o resto a esta. Nem isto; abstenção completa.

Pelo que toca ao ensino secundário, já o mesmo proceder não seria acertado no Brasil, isto é: deixal-o por toda a parte entregue á nação mesma, que procurasse sahir do embaraço por meio das associações, confrarias, indivíduos, etc., conforme a capacidade de que se mostrassem dotados, esperando que a concurrencia tivesse, n'este terreno, em si mesma a indispensável correcção. A União deveria reservar para si, n'este ramo de ensino, o direito de dar na Capital Federal o modelo, que se imporia não só pela obrigatoriedade legal, mas ainda pelos methodos e pelo pessoal docente.

Á abstinência completa no ensino superior, deixado á sociedade, o Estado Federal, a União juntaria no secundário, a intervenção forte no centro.

E o ensino primário?

Aqui a cousa muda muito de figura. A União deveria resolutamente, radicalmente occuparse d'elle por toda a vastidão do paiz. As razões são as seguintes:

O ensino primário é a paga inadiável que o Estado deve a todo o cidadão brasileiro, como cidadão, desde que o priva de votar quando é analphabeto (Art. $70, \S 2^{\circ}$. da Const.). $\mathrm{O}$ ensino primário é a arma que toda sociedade moderna é forçada a dar, como ponto de partida, na lucta tremenda da organisação econômica da actualidade, onde o trabalho é cheio de terríveis exigências impostas pelo capital. É, nas sociedades democráticas onde o governo não existe por favor de Deus ou dos grandes, mas por necessidade do próprio povo, a condição mais elementar do exercício do mesmo governo. Não involve questões 
transcendentes de doutrina, que corram o perigo de chocar as crenças de quem quer que seja, á vista de sua própria elementaridade, e por isso pode e deve ser uma funccção publica geral. Não importa n'um luxo, não passando, ao envez, da mais urgente necessidade. Não é technico e especialisador a ponto de requerer differenciações; é igual e o mesmo para todos.

É conveniente retiral-o dos vai-vens e baixezas da politiquice aldeante e dar-lhe um tom em que a pátria, a grande pátria sobrepuje a tudo. É, dest'arte, um agente robusto e poderoso e facílimo de união, de consolidação dos laços nacionaes, que se vão afrouxando desoladoramente.

Assim como aos nossos Estados, por maiores que sejam e mais populosos, se lhes deveria marcar um maximum as suas milícias, a primeira providencia para que elles, os Estados grandes, não suffoquem os pequenos na Federação, como o faziam no Imperio, e a segunda para que não organizem verdadeiros exércitos, que, unidos os de dois ou três, excederão de muito o exercito nacional, assim também o ensino primário, como a principal pedra a formação do caráter do povo, deveria ser um predicado do governo geral.

Cremos ser esta hoje a tendência nos próprios Estados Unidos e o facto na Inglaterra, duas nações que sabem o que fazem. Oxalá podessemos n'este ponto imital-as!" 